the conveyances were unloaded, the least injured were assisted to the hospital.tent, while the more dangerously wounded were carried. The whole were again examined, and sucb as were supposed to require it were got ready to have their limbs amputated : for instance, a case of gunshot wound with fracture of the tibia was treated with a plasterof-Paris splint (Bavarian method), and which a man of the Army Hispital Corps applied in an incredibly short space of time. After this, Major-General Lysons inspected the men, and expressed himself much pleased with what he had witnessed, and stated his intention of making a very favourable report to his Royal Highness the Field.Marshal Commanding-in-Chief. To give an idea of the scope of training these men receive, the following list of subjects taught (at the Army $H_{i r p p i t a l}$ Corps Training Sebool at Aldershot) is appended:-Outline of the general anatomy of the buman body; bandaging; treatment of fractured bones; the dressing of sores, gunshot and other wounds and injuries; the administration of medicines and the application of external remedies; the management of hospital wards, and nursing patients generally; the immediate treatment of the apparently drowned, and cases of fits, burns, scalds, frostbites, poisoning, and other emergencies; the names and uses of medical, surgical, and other appliances, and the instruments required for operations ; the first assistance to be rendered to wounded on the field of battle; the mode of transporting wounded by stretchers, mule cacolets or chairs, mule litters, a mbulance waggons, railway, and improvised methods when no stretchers are available.

\section{HEALTH OF THE NAVY.}

THe statistical report of the health of the navy for the year 1875 , is issued as we go to press. With regard to the state of the Home station during that period, it would appear that there was little recorded worthy of note. There was a trifling increase in its sick rate and in its ratio of invaliding compared with the preceding year, but its deathrate was lower. The Contagious Diseases Acts are working much good and the advantages of their operation are fully recognised. On the Mediterranean station the continued prevalence of enteric fever, especially in Malta harbour, was the cause of a commission being appointed to inquire into its origin and enndition, the results of which are stated. On the North American and West Indian stations, owing to immunity from zellow fever, the total death-rate was only 85 per thousand. On the South-east coast of the American station the men were equally healthy. In one of the ships on the East Indies station cholera appeared and caused some mortality. Histories of the measles epidemic in Fiji, of an outbreals of enteric fever on the Australian station, and the results of inquiries made into the reputed poisonous nature of the arrows of the South Sea Islanders are recorded. Altingether the sanitary condition of the service afloat in 1875 was satisfactory. Compared with the preceding year there was a reduction in the ratio of cases of disease and injury to the extent of 37.5 per thousand; of invaliding 4.7 per thousand, and of mortality of 6 per thousand. We shall take an early opportunity of dealing with the various interesting features of the report.

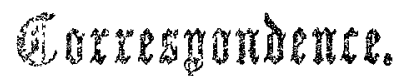

"Andi alteram partem."

\section{BLOODLETTING IN THE DAYS OF CULLEN.} To the Elditor of THE LANCET.

$\mathrm{SrR}_{3}$-I suppose all of your readers are acquainted with the following passage from Cullen's "First Lines:"-" There are persons who by their constitution are ready to faint even upon a small bleeding; and, in such persons, this may prevent the drawing so much blood at first as a pneumonic inflammation may require; but as the same persons are sometimes found to bear after-bleedings better than the first, this allows the second and subsequent bleeding to be larger, and to such a quantity as the symptoms of the disease may ceem to require." *

Now, it has already been repeatedly shown by quotations from Callen's own clinical lectures, and from others of the same period, that the ordinary run of pneunonic patients seen by him was in erery respect precisely similar to what we see now-a-days. It seemed, therefore, that if we could ascertain the precise amount of blood the withdrawal of which induced faintness in the individuals referred to, and if we could further discover what was the average ratio of prevalence of such peculiar constitution in Cullen's days, we should have a very accurate measure of comparison between the constitution of the average Briton in our own days and that of his predecessor one bundred years ago, quoad bloodletting at all events. In all the vublished editions of Cullen's work, there is, however, no bint of the information required; the paragraph in each of them stands exactly as I have quoted it. In the Library if the Royal College of Physicians here, we have, however, Cullen's own copy of the second edition of the " First Lines," interleaved, and with copious MS. notes in his own handwriting. In this copy, after the words "small bleeding," we have the symbol "iv. $\xi$ " introduced in Cullen's own bandwriting. This, then, was the amount of blord the withdrawal of which was sufficient to induce faintress in a certain number of patients in Cullen's days, and as I fancy there can be no great number even yet who could not bear at least this amount of bloodletting without fainting, so there can be no great difference between our constitutions and theirs. At the conclusion of the paragraph quoted Cullen appends another MS. note: "This fact and rule hold very universally." Now, if the "fact" thus referred to signifies the prevalence of persons ready to faint upon so small a bloodletting as four ounces, it reveals a state of matters which, to say the least, is not better than what now exists; while, on the other hand, if it be beld to refer to the statement that the "same persons are sometimes found to bear afterbleedings better than the first," it at all events indicates that Cullen must have had some considerable experience in this class of cases before he could make so strong a statement. These annotations of Cullen's are extremely interesting, and indicate pretty clearly that our hospitals might still be streaming with blood if the acting physicians possessed the same faith as Cullen, or one-tenth of the credulous boldness of his followers, such as the celebrated Dr. Butter, who in a case of phrenitis actually cut down upon the carotid artery, and was only with difficulty prevented from opening it.

Nov. 25th, 1876.

$$
\text { I am, Sir, yours obediently, }
$$

\section{DUTIES AND POWERS OF A MEDICAL OFFICER OF HEALTH. \\ To the Editor of THE LANCET.}

SrR,-A mongst the Annotations in your issue of November 25th, 1876, are some remarks with the above heading, apropos of the recent case before the Court of Queen's Bench of the Medical Officer of Health of Harrogate versus the Local Board of Health, in which the Lord Chisf Justice expressed the following opiaions as to the relations which are recognised by law as subsisting between medical officers of health and inspectors of nuisances:-

"The order of Dr. Deville, as officer of health, is in itself sufficient to make it obligatory on the inspector to do his duty, and though the Board tell him not to perform his duty and obey the lawful orders of the officer of health, he is bound to obey. . . . . They have no right to give the inspector instructions as to his discharge of his duties. The Act gives them no such authority; it is vested in the officers of health. ryeir order to the inspector not to obey him is mere brutum fulmen, and will not protect him from the consequences of his disobedience of the lawful orders of the officer of health. Mrr. Justice Mellor and Mr. Justice Lush concurred."

As a medical officer of health of great experience, who has had and now has the supervision of large districts, each of which is provided with its inspector, and as one who knows

$$
\text { * Second Edition, Edin. } 1778 \text { : section ccexlvili, p. } 279 .
$$

